\title{
The development of a constructivist socio- cultural model of professional development from 1970s to 2011
}

\section{O desenvolvimento de um modelo construtivista sociocultural de formação profissional: de 1970 a 2011}

\author{
Harriett S. Stubbs ${ }^{1}$
}

\begin{abstract}
SCI-LINK: A Model of Professional Development, had its earliest beginnings in the mid-1970s. A brief overview of this constructivist, sociocultural model is described, as referenced through many papers written as the model 'expanded' over time and incorporated other programs. SCILINK is a fluid model. Certain of its various projects and component parts have been addressed in publications spanning 1978 to the present. These components have focused on information requested by teachers about new environmental topics such as acid rain, air quality, water quality, harmful algal blooms, mosquito borne diseases, urbanization; on new technology applications such as geographic information systems (GIS), the Internet, use of computers in classrooms; or on personal development such as What is a leader? What exemplifies a good teacher? How can I take charge of my own growth and development? The SCI-LINK model is 'based on a conceptualization of professional development as the empowerment of individuals through a process in which they are given the tools and the opportunity to construct their own knowledge and meaning in a supportive social context." (HOWE; STUBBS, 1998², p.179).
\end{abstract}

Key words: professional development; teacher continuing education; science education.

1 Ph.D. Emerittus professor at the North Carolina State University.

2 This paper received the 1998 Implications of Research for Educational Practice Award of the Association for the Education of Teachers in Science (AETS). 


\section{RESUMO}

SCI-LINK: Um modelo de formação continuada de professores teve seu início em meados de 1970. Uma visão geral desse modelo construtivista sociocultural é descrito e referenciado por muitos artigos escritos, enquanto o modelo se expandia ao longo do tempo e incorporava outros programas. SCI-LINK é um modelo fluido. Seus vários projetos componentes e partes foram discutidos em publicações desde 1978 até o momento atual. Esses componentes focalizaram nas informações solicitadas pelos professores sobre novos tópicos ambientais como a chuva ácida, a qualidade do ar, da água, desenvolvimento exagerado de algas perigosas, doenças causadas por mosquitos, urbanização, novas aplicações tecnológicas como o Sistema de Informação Geográfica (GIS), a internet, o uso de computadores em sala de aula, ou no desenvolvimento profissional, tais como: O que é um líder? O que caracteriza um bom professor? Como eu posso me responsabilizar por meu próprio crescimento e desenvolvimento profissional? $\mathrm{O}$ Modelo SCI-LINK é "baseado na conceptualização do desenvolvimento profissional fortalecendo indivíduos por meio de um processo no qual eles recebem as ferramentas e a oportunidade para construir seus próprios conhecimentos e significados em um ambiente social de apoio." (HOWE; STUBBS, 1998, p.179).

Palavras-chave: desenvolvimento profissional; formação continuada de professores; educação em ciências.

\section{Introduction: SCI-LINK/ GLOBE-NET}

This paper reviews SCI-LINK, a program that had its beginnings in the mid 1970s, in several classrooms in Minnesota, when a few scientists and teachers developed a plan to study a newly emerging environmental topic, acid rain, with their students. As the Title IV-C program grew to include many more individuals supported by many different entities, from schools, school districts and professional organizations, The Acid Rain Foundation, Inc. aided in the information dissemination of scientific and technical information to many different audiences, including the curricula developed by and for science teachers. SCI-LINK, a teacher enhancement program which links current environmental scientific research with scientists, teachers and students (ANDERSON, 1993) was awarded support by the National Science Foundation (NSF) in 1991 with a major 3 year grant. In 1992, NSF awarded a second grant, GLOBE-NET (STUBBS; ANDERSON, 1995). These two programs provided a framework: 
first, to provide professional development for educators, and secondly, to develop and publish instructional materials on global environmental change for classroom use (STUBBS, 1983; ANDERSON; STUBBS, 2001; SCI-LINK/ GLOBE-NET, 1996).

All of these programs and connected projects were based on the following facts:

Teachers are interested in new ideas and information; teachers want to take this new knowledge back to the classroom; teachers are skilled professionals, trained in their science subject areas, competent in teaching, knowledgeable of their students and curricula, and are the best people to translate new ideas and knowledge into classroom practice (STUBBS, 1983; HOWE; STUBBS, 1998; SCI-LINK/GLOBE-NET, 1996).

Subsequently, many different projects have been incorporated into SCI-LINK, and other individuals have joined the network. The goal continues to be linking scientists, teachers and students to produce programs for teachers on new topics of vital environmental concern and to develop and publish instructional materials on these topics. For the past thirty years, teachers have requested such topics as: Use of Computers, Introduction of Technology, Developing Leaders, Learning GIS, Air Quality, Water Quality, and other topics related to environmental concerns.

\section{A constructivist/socio-cultural model for professional development}

In 1992, Dr. Ann Howe joined the project as Evaluator. She collected data through telephone surveys, focus groups, available records, and observations. She described The SCI-LINK Model as a "constructivist/ socio-cultural model for the professional development of science teachers ..." in a paper entitled Empowering Science Teachers: A Model for Professional Development (Howe $\&$ Stubbs, 1998). This paper received the award for "Implications of Research for Educational Practice" in 1997 from the Association for the Education of Teachers in Science (AETS - now known as ATSE). Description of the SCI-LINK Model is aided by Howe's evaluation of teachers within the project - and the teachers' comments are revealing. 
In summary, there were two recurring themes the science teachers expressed: "We were treated as professionals" and "We learned so much from each other." (HOWE; STUBBS, 1998, p.178). Howe and Stubbs (p.179) state:

When teachers have the freedom to make choices and to take responsibility for their own futures as professionals, they gain a sense of their own power, which is to say, they become empowered. The data that we have gathered indicate that many teachers have accepted the challenge to take charge of their own professional and personal growth and the result has been that they have a new sense of their own worth and power.

Many of the SCI-LINK teachers continued to develop both personally and professionally within the workshops, becoming leaders of other teachers (BRAY, 1998). Howe (HOWE; STUBBS, 2003) investigated the process by which three science teachers became effective teacher leaders in their school, their profession and their communities. Howe compared the SCI-LINK Model to a leadership development framework (PALUS; DRATH, 1995; DRATH, 1996) proposed by researchers outside the education profession. Howe identified elements in the process of reorganization of the individual's thinking as proposed by Palus and Drath (1995). Readiness for development of the individual is essential. Disequilibrium is part of the process resulting in new meanings that are developed and accepted. Each individual has potential for continued growth and development which aids in identifying new outcomes with a new capacity for effective action.

To be most effective, a leadership development program helps participants actualize the potential created by the program through some form of long-term support. This support may consist of many possibilities such as follow-up meetings, opportunities for participants to get together in other contexts, or a continuum of activities begun in the program. These continuing activities can foster the creation of a community of practice among the participants that reinforces and stabilizes the new meaning structures that have developed.

Howe (HOWE; STUBBS, 1998) then compared these findings with the SCI-LINK Model, by interviewing three teacher-leaders in the SCI-LINK program, gathering the data, comparing to those elements delineated by Palus and Drath. We suggested there are four essential elements in any program designed to promote and support the development of teacher leaders (p.294). These are: Mutual respect between scientists and teachers; Challenging tasks; Creation of a Community of Practice; Opportunities for teachers to assume leadership roles. 
It is almost impossible for teachers to move into new roles when they are locked into a school structure that separates administrators from teachers and a schedule that allows no time for collegial interaction among teachers. Ongoing programs and opportunities for professional interaction are essential to leadership development, a long-term process that depends on opportunities for continued stimulation and support. We believe there are many teachers who are ready to become teacher leaders, but they do not have the opportunities, encouragement and stimulation that are needed.

There is room for many different programs and different models of leadership development that will provide the experiences, encouragement, knowledge, and support that teachers need in order to step forward and lead. (STUBBS; HOWE, 1998, p.297).

\section{Development of a network}

Ongoing professional development opportunities took different forms. Presentations have been made by SCI-LINK teachers at state, regional, national NSTA and NAAEE meetings, numerous mini-workshops in North Carolina, Minnesota, other states, and at international meetings. For ten years, an annual program known as Teacher Day, addressed various environmental/ educational topics in which scientists, teachers, and students were featured. Mini-workshops were requested by different school districts. Week-end workshops were developed. An annual one-week Grandfather Mountain Workshop was held in western North Carolina for 19 years. Teachers traveled to Minnesota for two-week Institutes; Minnesota teachers attended two-week Institutes in North Carolina. We are convinced that "Teachers are knowledgeable professionals who have the desire and ability to learn and grow." (STUBBS; HOWE, 1998, p.180). Development of a network is ongoing and continues.

Publications of the project included sourcebooks for teachers on Ozone, Algae, Lyme Disease, Acid Rain (3), Trees (ANDERSON; STUBBS, 2001) student project booklets, booklets for participants, newsletters, videos, photographs, listservs, blogs, and new technology components connecting participants. Teachers, scientists, authors, artists and students contributed to these publica- 
tions $^{3}$. These resources are increasingly important to those in the network, as technology changes and computer connections become increasingly available.

\section{Geographic Information Systems}

The topic pertinent to this paper is Geographic Information Systems (GIS) and the Brazilian connection. To better understand our process and the outcomes, we reviewed the SCI-LINK model, leadership development, and our approach to professional development.

A cadre of individuals from NC state agencies, including the NC Office of Environmental Education, NCSU, and others, thought GIS would provide a perfect learning process with positive outcomes for educators. In 1996, when the US Environmental Protection Agency provided funds for teachers to learn about hazardous waste in a GIS environment, it was the first time SCI-LINK teachers would use this technology. A university expert, Dr. Hugh Devine opened his lab, offered graduate student time, hosted teachers - and spent hours demonstrating GIS. Dr. Denis DuBay from the NC Department of Natural Resources, local city and state GIS personnel, education systems - all worked toward GIS Education. ESRI, a leading software company, hired Charlie Fitzpatrick to be in charge of GIS Education. Software for education could be requested; Fitzpatrick provided support and networking capability.

We began with most difficult computer applications - seeking help from graduate students, and experts within the university. Individuals from state agencies, experts in topic areas, university professors, city, and county managers, individuals from different states and countries - all attended these workshops as experts and provided assistance. Teachers in different disciplines, educators of environmental education - even kindergarten teachers, and those from NGOs - came to learn about GIS.

These workshops aimed to support individuals in the use of environmental data to solve problems, and how to use technology new to them. Workshop participants subsequently developed their own individual activities to introduce these concepts to students in their classrooms grades 5-12, museums, nature centers, and other non-formal locations (STUBBS; DEVINE; HAGEVIK, 2002; DuBAY; STUBBS 1996).

3 Refer to the SCI-LINK publication website to see all the publication list and links http:// www.ncsu.edu/scilink/publications.htm. 
It may have been one of the first programs in the state attempting to introduce this new technology and its way of thinking to educators. GIS had been utilized in industry and in government agencies for 25 years, but had not been introduced to educators.

The initial software was much too difficult for our 5 day or 10 day teacher workshops. Each teacher was given 'step-by-step' direction pages - long and tedious for all of us. Just learning the steps and the software required hours of work - appropriate for undergraduate or graduate students working on credit classes, but not for short professional development workshops for teachers. However, many participants were persistent, recognizing the value of these data sets and approaches.

To reach educators across North Carolina, and to specifically overcome perceived barriers to introducing this more complex technology tool, a conceptual plan was developed by workshop organizers and teachers, entitled the 5-Step GIS Leadership Model (STUBBS et al., 2000; STUBBS et al., 2003). At this time, the software was difficult for teachers to use, and the 5-Step Model was a method to facilitate the learning of this software.

The 5-Step GIS Leadership Development Model is a graduated program composed of a five-step series of workshops and projects. It includes a leadership component which enables teachers to become mentors and workshop instructors for other teachers. Through their teaching of others, educators demonstrated increased learning and application of geographic information systems. A brief overview of each of the 5 steps follows, indicating the focus and software used (STUBBS; DEVINE; HAGEVIK, 2002; STUBBS et al., 2003). Each workshop focused on a specific area of the environment, and was taught through presentations by scientists, information personnel, GIS professionals, using educational applications. A field component was essential.

In addition, management and pedagogy related to the implementation and integration of science, math, and technology into instruction were addressed. These workshops were NOT simply learning how to use software programs but WERE about gaining specific knowledge using technology applications as tools for further analysis, understanding, and learning. For example, workshops in the first three years focused on the environmental topic of hazardous waste. Workshops in the later years furthered knowledge of non-point source pollution, or polluted run-off - problems of water pollution. Fortunately, the software has advanced tremendously and data is now available on line in many different topics.

There were implications beyond education K-12. One of the SCI-LINK teachers was elected to the city council of a neighboring town. When the town was considering the placement of a new sewage system, she insisted GIS experts be brought in to help in the decision making. She was the only person on the 
board able to explain why GIS was so important; she was a true example of community outreach by a SCI-LINK teacher..

\section{Overview of the 5-Step GIS Leadership Model}

A graphic representation of the 5-Step Model can be found online at www. ncsu.edu/meridian/sum2003/gis/

All workshops focused on an Environmental Topic. Some topics of past workshops included: hazardous waste, river basins, watersheds, health issues, and polluted run-off.

- Step I. Introduction to maps, spatial thinking, and learning about an environmental problem. ArcVoyager GIS software.

- Step II. Mapping a specific site, monitoring components and parameters of this environment (plants, temperature, animals, cover, water and run-off, and non-living components such as soil and air). GPS, GLOBE protocols, CityGreen, hand held devices, ArcView 3.x. The MOSS Mapping Our School Site has been utilized.

- $\quad$ Step III. Community focus, field trips to compare various environmental factors at different locations. Individual project developed. Beginning GIS using ArcView 3.x.

- $\quad$ Step IV. Individual project developed by each educator augmented with an APlan, specific to educator home site, incorporating community partners. Advanced GIS using ArcView 3.x.

- Step V. Each educator is responsible for developing his/her individual project. Three days in the classroom, (two days with supervision by graduate students) and one day with subject matter experts. Two days in the community, contacting cooperators and specific partners for each project, following the design of the APlan. Complete project plans submitted for review. GIS, CityGreen, ArcVoyager.

As we wrote and believe important and still pertinent in 2011, almost ten years later:

We are at the beginning of an explosion and expansion of the use of environmental data to solve problems - from the development of school bus routes, to the solution of crimes, environmental controls, city and open-space planning, flood and fire mapping, emergency management, and 
many more. I $t$ is important that all students learn how to use technology in their every-day lives and to be technologically prepared for the jobs of the future (STUBBS; DEVINE; HAGEVIK, 2002).

The lifelong learner, the thinking explorer, the guide with vision and passion. ...it is encouraging that ... some students get to focus on integrative, real-life projects with significance to the world around them. In coming years, the students... will be prepared to solve problems by finding data, sifting out the relevant material, integrating varied sources, analyzing relationships, collaborating with others, and communicating their findings (FITZPATRICK, 2000, p.vii).

\section{Leadership Component of the 5-Step GIS Model}

All educators, as they participate in the 5-Step Leadership Model, are required to teach each step, receiving a certificate as each step is completed. After completion of the 5 Steps and the 5 Steps Leadership, educators then receive 3 graduate credits (equivalent for their work) in the College of Natural Resources at North Carolina State University.

Four projects are mentioned as exemplary examples of what can happen in formal and non-formal settings (STUBBS et al., 2003). (Please see a paper in this issue authored by D. Whitaker). Hagevik, utilizing SCI-LINK publications and the GIS workshops, developed a curriculum, MOSS (Mapping Our School Site and Step II of the 5-Step Model) that has spawned a number of individual projects. Online at www.ncsu.edu/scilink (Please see a paper in this issue authored by R. Hagevik).

Members of the state-wide North Carolina GIS Consortium, representing a collaborative network of individuals from state agencies, professional organizations, corporations and universities have advised and made major contributions for these projects over a period of years. This network has been vital for the growth and advancement of the application of GIS and related technologies to the public and in the further education of students (STUBBS; DEVINE; HAGEVIK, 2002).

Our project spearheaded the beginning use of GIS by educators. Today, a number of years later, the use of geospatial technologies in the education community has mushroomed and the demand for individuals trained in the use 
of these technologies has provided employment for many graduating with these skills. The NC Department of Labor has impressive projected job openings and growth http://www.onetonline.org/link/summary/15-1099.06 and the NC GIS Coordinating Council at http://www.ncgicc.com/Committees/StateGovernmentGISUsersCommitteeSGUC/tabid/165/Def ault.aspx provides further information. The new NC State Master's Program of Geospatial Information Science and Technology degree (and related programs) at http://www.gis.ncsu. edu/ illustrates the growth within this institution. The NCGE National Council for Geographic Education is an essential contact for educators.

\section{The brazilian connection}

In 2000, the Department of Mathematics, Science and Technology Education in the College of Education at North Carolina State University received a graduate student from Brazil. Christiane Gioppo stayed at my house for a month until she could find housing ${ }^{4}$.

When IOSTE held their international meeting at Iguazu Falls, Brazil, Gioppo encouraged all of us to attend and to present our work on GIS. Many of us were members of IOSTE; five of us went to Brazil, establishing friendships with others, networking with those in another country. A paper presented, then submitted for inclusion in the proceedings, work by Dr. Hugh Devine, chair of the university GIS program and Dr. Harriett Stubbs, SCI-LINK/ GIS ED, College of Education and her work with teachers; and Rita Hagevik, Graduate Student, who was developing an on-line course. Included is a quote from the paper we presented:

A collaborative network has been developed over a period of years, of individuals from state government, university, corporations, and schools $\mathrm{K}-12$. This network is expanding as more and more individuals take

4 You from Brazil will appreciate this aside. The first week she was here, in a strange location, with no car, I had to go out of town. The night I left, there was a storm here in Raleigh with about 22 inches of snow (most unusual). Here was Christiane, alone in a house she did not know, with no snow shovel, no food, no transportation. What a welcome to North Carolina and to the U.S. How would you feel? When I got home a week later, I had to uncover and shovel my car out at the airport! Christiane helped me through deep snow and ice in the yard so that I could get back to my house!!! (This is an aside anecdote) 
classes, workshops, and seek additional experiences. This network is vital to the growth of knowledge and technology application in universities, schools, non-formal organizations, and communities (STUBBS; DEVINE; HAGEVIK, 2002, p.35/287).

In 2003, Gioppo brought five of her Brazilian students from Curitiba, Brazil to Raleigh, North Carolina, to attend the SCI-LINK GIS Workshop and Grandfather Mountain Workshop, each one week in length. She had attended and was familiar with the content, methodology and outcomes. Two additional faculty members from the Federal University of Paraná accompanied the students to assist them with their work in the U.S. and future efforts in Brazil.

This was the first time we had university faculty attending our workshops to assist students. Another attendee was from a Sao Paulo education firm. An administrator and two teachers from Finland also attended the Grandfather Mountain Workshop. It was an excellent opportunity for discussion and comparisons between the Brazilian educational system (one of the lowest ranking in PISA scores) and Finland (one of the highest ranking in PISA scores).

After the workshops, the Brazilian students and faculty returned to Brazil to continue their work. Gioppo has documented the student work over time in the publications Gioppo (2004); Gioppo \& Barra (2005); Gioppo, Silva \& Barra (2006).

One student focused on bats, one student researched the dengue fever mosquito, and another studied forests - all used GIS. One faculty member used GIS in Brazil, but was introduced to the different software used in the U.S. After a recent listserv was mailed October 2010, (eight years after the Brazilians visited the U.S.), the following email was received:

Hello Dr. Stubbs!!!

How are you? It was great to read this e-mail (list-serv mailed bi-monthly) and see how many things are happening in the SCI LINK Program. 
I also enjoyed to receive news about Kari Nuuttila (from Finland), Ingrid Imenez (from Brazil), Chris Gioppo and Donizetti Giusti. It made me remember the great moments I had with all of you in the summer of 2003.

I also have great news to share. After finishing my Master's Degree in 2006, I started working as a Biology teacher in a new High School in Curitiba, Colegio (name and site), which belongs to the Industry Federation of Paraná. In the beginning of this year I was invited to become Principal at this school, being responsible for a group of 36 teachers and 960 students. It is a great responsibility, but I am enjoying so much to work with School administration.

I'm also helping to implement the 5th to 8th grade at a Elementary School named (name and site).

I am so involved with education right now, and I have to thank you for that, because the experience I had in North Carolina was very important for me as a teacher!!!

I want apologize for my English (I haven't been practicing enough)...

My best wishes,

Name left anonymous for this paper (personal e-mail message received in 2011, Highlights by Stubbs)

Another comment from a Brazilian, 2009 (translated): "I learned the importance of ecological balance and I realized that the work we do at home and in schools (recycling, energy conservation, water use, respect for all life....) reflects ecosystems. We are part of everything that exists, therefore we as educators have a great responsibility!" (2009 non-published workshop evaluation)

Brazilians have attended our workshops for eight years; the Finns attended for nine years. They have attended state, national and international workshops and meetings of the National Science Teacher Association (NSTA), North American Association of Environmental Educators (NAAEE), and others, presenting their work, submitting papers, continuing the networking begun years before. They have added immeasurably to the American experience within workshops - it is essential this type of global interchange continue! Gioppo attended various workshops, graduate classes, and returned to NCSU to complete her PhD degree in Science Education (GIOPPO, 2004). Gioppo directed the SCI-LINK Amazon Summer 2009 experience for a group of educators from the United States and from Brazil. 


\section{Other programs}

Components of the SCI-LINK professional development model have been applied in other projects. A few of these are: TELEE, a connected-by-television course that linked four universities (SPENCE; STUBBS; HUBER, 2000); Fundamentals of Environmental Education 2008 - an environmental education online course; Air Quality Resources for Teachers (CUNNINGHAM; STUBBS, 2003); Brazil: Adventures in Ecology and Education 2005-2011 (STUBBS, 2008; 2009; STUBBS; GIOPPO; McNAMEE, 2009) in the study of Brazilian culture, animals, plants, birds and people.

Stubbs was invited to spend a month in Brazil as a Visiting Scholar, going to work every day, meeting Brazilian co-workers, and listening to Portuguese. Unique opportunities were offered to her and she was introduced to the Brazilian culture. As a result, the project Brazil: Adventures in Education and Ecology was introduced. Educators travel with Brazilian educators for ten days to a large metropolitan city and to the Pantanal. It is now in its $7^{\text {th }}$ year. Important to all involved is the global perspective and opportunities for learning about a Latin American country that is growing exponentially. Please refer to the website for further information: www.ncsu.edu/scilink and note the articles in the NCSU online journal Meridian pertaining to Brazil (also in Portuguese), and the international SCI-LINK experiences (STUBBS, 2008; 2009; STUBBS; GIOPPO; McNAMEE, 2009).

\section{Further research}

There are many questions to be answered in future research projects. Can it be predicted which teachers might benefit from this model? Will teachers be more creative in their approach with students? Will teachers teach differently? Will teachers allow students their own individual differences and allow students to develop their own talents? There may be certain components of the model that teachers utilize immediately. What are these elements? Can teachers adjust to being a facilitator? Can teachers be cooperative, as compared with competitive? The required duties of the classroom teacher, combined with the economic situation in our country today, does not bode well for the individual teacher. Teachers are not identical like cookie cutters, nor are students 'widgets' as on 
an assembly line. We must provide for individual differences and growth, so that each individual can reach his/her own potential. Can we?

\section{Conclusions}

It has taken many years to develop, test, and evaluate different component parts of what we now think can be considered the SCI-LINK Model of Professional Development. Each project has had its own evaluation, its own objectives and its own outcomes. It has taken more time to understand what has occurred, to decide important components, transfer methodologies and strategies to other projects, and test and evaluate the model in other situations. .... From one classroom in one city in one state, to international extraordinary experiences; from a homogeneous group of individuals to a heterogeneous mix of peoples ..... Only now almost $30+$ years later, can we realize what was expressed in this collection of publications by many authors, as well as listening to those who have been in contact over many years.

Information dissemination linking scientists/ experts with teachers with students; participant developed curricula - applications of current environmental information, development of each individual to reach his/her own potential - all are important concepts of the SCI-LINK model of teacher professional development

New, creative approaches are demanded in the reform of education; essential are programs that broaden the horizons of all educators and students, allowing each to develop their own capacities and talents! For how can a teacher be a role model unless they themselves are excited about their teaching, able to relate to their students and inspire them so that their students will 'reach for the stars'?

The collaboration and cooperation of you many, has helped form the basis for this ongoing study. We hope we have added to the research findings of leadership development in a community of practice. We look forward to the development of international connections leading toward global significance in the teaching and learning of the future leaders of tomorrow. 


\section{Acknowledgments}

We wish to give thanks of appreciation to Christiane Gioppo for the opportunity to review this body of work from the mid-70s until the present, in presentations, publications, people, and networks, in preparation for this article

We wish to thank the many hundreds of individuals who have supported the SCI-LINK Program over a period of years. Many of you have professed individual and professional growth in the process - we thank you for your comments. You are from state government, universities, corporations, schools pre-K to 16 , nature centers, museums, public and private foundations, in local, state, national and international entities. Your generous participation, commitment of contributed time and monies has enabled the projects to provide informational material for educators and helped to translate current environmental science research into teaching practices.

\section{REFERENCES}

ANDERSON, N. D. SCI-LINK: A Project Linking Research Scientists and Science Teachers. Journal of Science Teacher Education, v. 4, n. 2, p. 44-50, 1993.

ANDERSON, N. D.; STUBBS, H. S. Algae: A Sourcebook for Teaching about Harmful Algae Blooms. Changes in the Environment Series. Dubuque, Iowa: Kendall-Hunt, 2001.

BRAY, N. Sci-Link/Globe-Net. Science Scope, v. 21, n. 6, p. 52-53, 1998.

CUNNINGHAM, W. P.; STUBBS, H. S. Information Needs Related to Teaching About Air Quality. Elsevier. In: Proceedings of Air Quality International Conference 2001 on Air Quality Resources for Educators. Environment International, v. 29, n. 2, p. 331336, 2003. Disponível em: <http://www.sciencedirect.com/>. Acesso em: 05 fev. 2011

DRATH, W. Changing our minds about leadership. Issues and Observations, Greensboro, v. 16, n. 1, 1996. 
DuBAY, D.; STUBBS, H. S. Geographic Information Systems and Environmental Education. In: Environmental Education for the Next Generation: Professional Development and Teacher Training, Selected Papers from the Twenty-fifth Annual Conference of the North American Association for Environmental Education. Troy, Ohio: NAAEE, 1996.

FITZPATRICK, C. Foreword. In: AUDET, R.; LUDWIG, G. GIS in Schools. New York, NY, 2000. p.vii.

GIOPPO, C. Designing and testing modules in non-formal education for teacher education candidates: a Brazilian experience. Unpublished doctoral dissertation. Raleigh, NC: North Carolina State University, 2004. Disponível em: <http:/www. lib.ncsu.edu/theses/available/etd-11092004-154419/>. Acesso em: 05 de fev. 2011.

GIOPPO, C.; BARRA, V. A avaliação em ciências naturais nas séries iniciais. Curitiba: Editora da UFPR, 2005.

GIOPPO, C.; SILVA, R. V. da; BARRA, V. A avaliação em ciências naturais no ensino fundamental. Curitiba: Editora da UFPR, 2006.

HOWE, A. C.; STUBBS, H. S. Empowering Science Teachers: A Model for Professional Development. Journal of Science Teacher Education, v. 8, n. 3, p. 167-182, 1998.

HOWE, A. C.; STUBBS, H. S. From Science Teacher to Teacher Leader: Leadership Development as Meaning Making in a Community of Practice. Journal of Science Education, v. 87, p. 281-298, 2003.

PALUS, C.; DRATH, W. Evolving leaders: a model for promoting leadership development in programs. Greensboro, NC: Center for Creative Leadership, 1995.

SCI-LINK/GLOBE-NET. Unpublished Progress Report to the National Science Foundation College of Education and Psychology. North Carolina State University, 1996. Dsponível em: <http://www.ncsu.edu/scilink>. Acesso em: 05 de fev. 2011.

SPENCE, L.; STUBBS, H. S.; HUBER, R. A. Using Collaboration and Interactive Technologies to Extend the Environmental Education Classroom: TelEE, a Description of an Interactive Telecommunication Course. T.H.E. Journal, v. 23, n. 2, p. 24-31, 2000.

STUBBS, H. S. Acid Precipitation Awareness Curriculum Materials In The Life Sciences. The American Biology Teacher, v. 45, n. 4, p. 217-225, April/May 1983.

STUBBS, H. S. Using Technology to Develop Global Teachers: An Innovative Model. Meridian Middle School Computer Technologies Journal, v. 2, n. 11, p. 1-13, 2008. Disponível em: <http://www.ncsu.edu/meridian/sum2008/stubbs/index.htm>. Acesso em: 15 de mar. 2011. 
STUBBS, H. S. Utilização da tecnologia para o desenvolvimento de professores globais: um modelo inovador. v.12, n.1, 2009. Translation: Mariana Reis with Patricia Maria Schubert Peres and Arlita McNamee. Disponível em: <://www.ncsu.edu/ meridian/winter2009/stubbs01/index.htm>. Acesso em: 15 de mar. 2011.

STUBBS, H. S.; ANDERSON, N. D. GLOBE-NET: A Partnership of Research Scientists and Teachers for the Development of Instructional Materials on Global Change. In: BOERSMA, K.; KOOS, K.; von TROMMEL, J. (Eds.). Proceedings of Science and Technology Education in a Demanding Society. Seventh International Symposium, International Organization of Science Technology Educators. Enschede, The Netherlands: National Institute for Curriculum Development, p. 817-832, 1995.

STUBBS, H. S.; DEVINE, H.; HAGEVIK, R. Thinking Spatially: GIS Curricula K-16 and Professional Development for Educators. In: BIZZO, N.; KAWASAKI, C. S.; FERRACIOLI, L.; da ROSA, V. L. (Eds.). Proceedings of the Conference: Rethinking Science and Technology Education to meet the demands for future generations in a changing world, Tenth International Symposium, International Organization of Science Technology Educators. Foz do Iguaçu, Brazil: International Organization of Science Technology Educators, 2002. p. 280-286.

STUBBS, H. S.; DuBAY, D. T.; ANDERSON, N. D.; DEVINE, H. A.; HAGEVIK, R. A. Using Environmental Science Utilizing Geographic Information Systems (GIS). Proceedings of the North American Association of Environmental Educators, Annual Conference. Rock Spring, Georgia: NAAEE, 2000. 4 p. CD-ROM.

STUBBS, H. S.; FOWLER, K.; BALL, J.; WHITAKER, D.; HAWLEY, B. Educational Environmental Projects, Using Technology Applications for Middle School Students in Formal and Non-Formal Settings. Meridian Middle School Computer Technologies Journal, v. 6, n. 2, 2003. Disponível em: <www.ncsu.edu/meridian/sum2003/gis/>. Acesso em: 17 de mar. de 2011.

STUBBS, H. S.; GIOPPO, C.; McNAMEE, A. Ecology, Environment and Education: Teaching and Learning in National and International Professional Development Experiences. Meridian Middle School Computer Technologies Journal, v. 12, n. 2, 2009. Disponível em: <www.ncsu.edu/meridian/sum2009>. Acesso em: 17 de mar. 2011.

Texto recebido em 10 de abril de 2011.

Texto aprovado em 29 de abril de 2011. 
